\title{
Strategies Model of Jember Historical Tourism Marketing
}

\author{
Lintang Anis Bena Kinanti. S.M.B., Dr. Bambang Irawan, M.Si., Dr. Novi Puspitasari, S.E., M.M.
}

Magister of Management, University of Jember Tegalboto Campus, Kalimantan Street 37, Jember Regency,

East Java, Indonesia

\begin{abstract}
Jember has a long history since prehistoric times, and is evidenced by the diversity of relics from prehistoric times to the colonial period. Historical heritage objects become important regional assets that can generate profits and have a significant effect on economic development. One idea that can be initiated is the presence of an ancient museum. Because of that, an effective marketing strategy is needed to increase the people's visit to the museum and other historical tourism. This study aims to explore how the condition of ancient sites and objects in Jember, explore how the potential of building a museum as a location for storing ancient objects in Jember, and formulating marketing strategies on historical tourism and museums as part of Jember tourism programs. This research adheres to the positivist paradigm using qualitative research methods, using a case study approach by exploring the condition of ancient objects in the Jember area in detail. The results showed that the collection of ancient objects from Jember's history varied greatly with a total of more than 600. A number of collections have been placed in the Antiquities Collection Room, with very limited maintenance, and the room conditions that are not yet representative. For this reason, museum is an alternative solution as a place to store ancient art collection, as well as a part of historical tourism in Jember. The formulation of marketing strategy departs from the concept of SWOT Analysis which is then synergized with the concept of Tourism Marketing Mix.
\end{abstract}

Keywords: Historical Tourism, Marketing Strategies, Museum, SWOT Analysis, Tourism Marketing Mix.

\section{Introduction}

Jember Regency has a long history since prehistoric times. This is evidenced by the discovery of a variety of relics of historical relics that are now become collection of cultural reserves with a considerable amount. The series of historical records are still illustrated in several inscriptions that are still in their original location. Civilized relics found in Jember Regency are classified in two major traditions, namely Old Megaliths and Younger Megaliths. Old Megaliths Period around 2,500-1,500 before centuries (BC). Whereas the era of the Younger Megaliths developed during the first millennium BC (Ahmad, 2015).

Based on data collected from the Department of Tourism and Culture of Jember Regency, the number of objects of cultural preservation that has been preserved is 601 pieces. While the number of cultural reserves that have been registered nationally are 158, and the number of cultural heritage objects found outside the site area are 43. All these relics show that Jember Regency actually has existed and has witnessed the history since hundreds, maybe even thousands of years ago. Even in the Negarakertagama book, there is a special chapter that explains about the journey of Hayam Wuruk to Jember. The diversity of archeological relics in Jember Regency never gets any portion at all in Indonesian historiography. The objects of cultural heritage are still largely left where they were found (in situ) (Widodo, 2014).

Jember Regency has a lot of potential of cultural heritage, almost from the entire historical period from prehistoric or ancient to colonial times in Jember Regency. One by one from the cultural heritage began to 
disappear from Jember Regency, making it difficult to trace back its existence. Items such as kenong stones, artifacts, menhirs, to krisses and other historical items were only placed in an area of no larger than 100 square meters, which was located in the Antiquities Collection Room in Patrang. Some of them scattered just like that in various corners without storage boxes, some even had to be put outside the room.

History and cultural heritage play important roles in the development of tourism. The potential history and culture of the country is one of the main factors of tourism (Ismagilova et al, 2015). Marketing is becoming an increasingly important part of the museum's core business strategy. Optimal efforts are needed in marketing historical tourism to the public and tourists so that the existence of cultural tourism can be known and utilized, to enhance and develop the attraction of historical tourism. The way is to develop historical tourism marketing designs from and for various parties. The implementation of a successful historical tourism marketing design can meet the needs of consumers for historical tourism visits and provide a change in the attitude of consumers or visitors who were initially less interested in historical tourism (Panosa, 2012). Tourism marketing strategies can be approached through the formulation of strengths, weaknesses, opportunities and threats, better known as the SWOT Analysis. Based on the phenomena in the background described above, it is important and interesting to do empirical research on the real condition of historical collections in Jember Regency and to know the efforts to save ancient objects in Jember Regency through the construction of ancient museums, and to formulate marketing strategies of ancient museums and historical tourism as part of regional tourism.

\section{Literature Review}

Lamb, Hair, and McDaniel (2011) describe marketing strategies as steps that involve selecting and describing one or more target markets and developing and maintaining a marketing mix that will produce a mutually satisfying exchange with the target market. Kotler and Keller (2012) define marketing strategies as a step to determine the mission, marketing goals and financial goals, and the needs offered by the market that can be satisfied, and competitive position. All of this requires input from other fields, such as purchasing, manufacturing, sales, finance, and human resources. Marketing strategies are used to give awareness to prospective customers about the products and services that will be offered, then develop a customer base. Peter and Olson (2013) describe marketing strategies as the design, implementation, and control of plans to influence exchange in order to achieve organizational goals. Marketing strategies involve developing and presenting marketing motivation directly to selected targets to influence what they think, how they feel, and what they do.

Marketing strategies planning can be explained in the following figure:

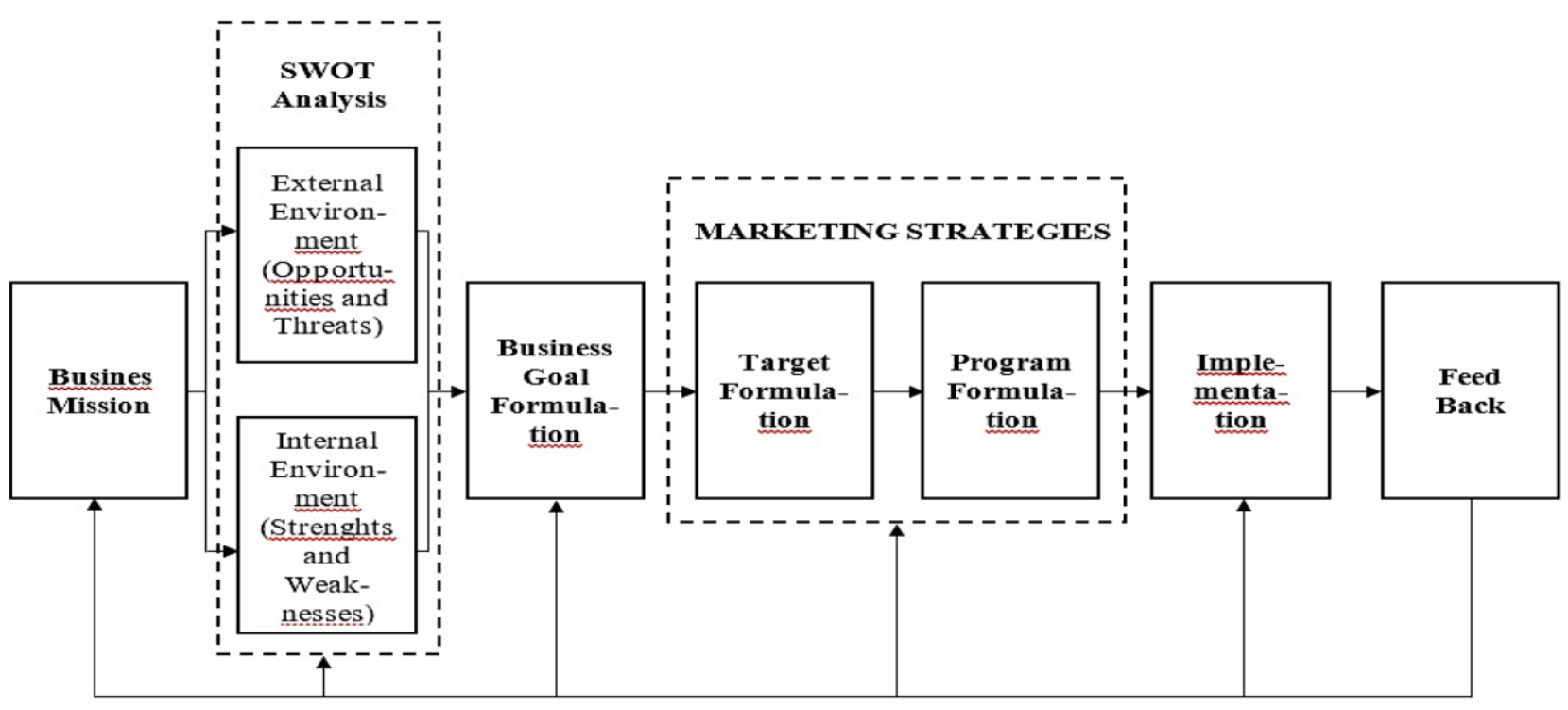


Hasan (2015) defines tourism as a human, cultural and hospitality business, requiring human resources with the right position, skills and jobs. The main challenge for tourism is the development of staff quality. Tourism requires a tourism network with a level of discipline that is able to display the character of the zone. In this zone tourists can be mobile smoothly and freely to satisfy their consumption desires. Tourism marketing is a coordinated system of carrying out various policies for companies of the tourism industry groups both individually or privately owned or government agencies, both local, regional, or international, to achieve tourist satisfaction (Suryadana and Octavia, 2015).

Lamb et al (2011, 38-39) describe SWOT analysis as a tool to identify internal strengths and weaknesses, and also examine external opportunities and threats. When examining external opportunities and threats, marketing managers must analyze aspects of the marketing environment. This process is called environmental scanning, which is the collection and interpretation of information about forces, events, and relationships in the external environment that can affect the organization's future or implementation of marketing plans. Whereas when examining internal strengths and weaknesses, marketing managers must focus on organizational resources such as production costs, marketing skills, financial resources, corporate or brand image, employee capabilities, and available technology. Rangkuti (2018) explains the SWOT analysis as a systematic step in identifying various factors for formulating corporate strategies. This analysis is based on logic that can maximize strengths and opportunities, but can simultaneously minimize weaknesses and threats.

\section{Methodology}

This research adheres to the positivist paradigm using qualitative research methods. This research uses a case study approach by exploring a condition, namely the maintenance of ancient objects in the Jember Regency in detail, accompanied by extracting data from informants who understand the situation. Besides that, it also explores how the real condition of Antiquities Collection Room in Jember Regency, knowing the efforts to save the ancient objects of Jember Regency as part of regional tourism through the construction of an ancient museum, and formulating a marketing strategy that can be used for historical tourism in Jember Regency.

The location of this research is located in Jember Regency. This research uses primary data and secondary data. Primary data is data obtained directly from the original source, and in qualitative research primary data sources are obtained from informants. Eight informants were selected from among the regional policy holders, architects of ancient sites, observers of the history of Jember Regency, marketing academics, and history academics. Secondary data is obtained indirectly or through other parties, such as archives, documents, print and electronic media that are relevant to the research topic. Data collection methods used were interviews, observation, and documentation.

Data analysis in qualitative research was carried out since before entering the field, while in the field, and after completion in the field. The data validity test that often used in qualitative research is the internal credibility or validity test, and the validity analysis technique used is triangulation. All data in this study obtained from observations, interviews and documentation have undergone a process of triangulation to achieve the research objectives.

\section{Result and Discussion}

Tourism products cannot be marketed in exactly the same way as manufactured products, because they do not give physical ownership to consumers. The production and consumption of tourism services only occur at predetermined locations to enjoy the promised services. Historical tourism marketing requires related parties to communicate with potential tourists so they want to visit historical sites. Tourism marketing mix can be an alternative to find out the variables needed in marketing historical tourism in Jember Regency. In 
this research, the marketing mix used is an amalgamation of Kotler and Keller's marketing mix theory with tourism marketing mix theory. The marketing mix aspects used are Product, Price, Place, Promotion, People, Process, and Physical Evidence. All aspects will be explained in the following sections.

\section{A. Product}

Products in historical tourism in Jember Regency are ancient collections and cultural heritage that are spreaded in all corners of Jember Regency. Not only the collection of prehistoric era, but also from the colonial era. The types are as varied as statues, sarcophagus, ancient coins, prehistoric bricks, reliefs, dolmen or megalithic tomb, inscriptions, and so forth. In addition, there are also in situ ancient sites which are still in their original location. These objects often get victory in national and international level contests. Such collections can't be found in other regions or countries.

In the product aspect there are four additional criteria namely Attraction, Accessibility, Facilities, and Ancillary. These four criteria in relation to historical tourism in Jember Regency will be explained as follows:

- Attraction. The attraction of historical tourism in Jember Regency is the collections which are not widely owned by other regions. These collections have proven to be a special attraction, and are able to bring both domestic and foreign tourists. Even the National Geographic and World Wide Fund, who visited the prehistoric collection of Jember Regency, were very impressed with the collection of historical relics in Jember Regency. This proves that Jember Regency has an ancient collection that is not inferior to other countries. In addition, residents and tourism-aware groups at some ancient site sites develop art shows that are displayed when tourists visit. This aspect of attraction can still be added if the existence of the museum would be realized. This museum can be functioned as a learning center as well as information about the history of Jember Regency. Tourists who come to Jember Regency can come to the museum if they want to know the ins and outs of Jember Regency from the prehistoric era to the present.

- Accessibility. A number of ancient site locations still do not have affordable transportation access. The reason is some ancient relics are still in their original locations in remote areas. This is an obstacle for local governments and tourism- aware groups. To overcome this, the local government can cooperate with transportation providers and travel agents to provide historical tour packages as well as providing transportation for tourists. A number of research informants agreed that if the existence of the museum would be realized, the location must be easily accessible to the public and tourists, both by public transportation and private vehicles. In addition, transportation facilities to and from Jember Regency are also sufficient. Like airports and trains with fixed schedules every day. These facilities can make it easier for tourists to come to Jember Regency.

- Facilities. Historical tourism can be synergized with cultural tourism. Therefore, cultural events can be held at cultural tourism locations. The same concept can also be applied in the history museum of Jember Regency. The museum area can be equipped with supporting facilities for public spaces such as buildings or halls that can be used for arts and cultural performances. This can make the museum as an integrated area of art and culture. Other facilities that can be added are the library and digital learning area that displays historical content in Jember Regency.

- Ancillary. Additional facilitiy that can be developed to support historical tourism in Jember Regency is the availability of travel agencies or travel agents. The stakeholder, in this case are the Jember Regency Government, has synergized with the travel agent manager to provide various historical tour packages for Jember Regency. This synergy can be enhanced by adding other facilities such as tour guides that can be taken from the local community. Other 
additional facilities can be added in the museum area such as ATMs, restaurants, hotels and lodgings, health centers, terminals / stops, souvenir shops, and children's play areas. The completeness of this museum area can be one of the other attractions to invite tourists to visit the museum

\section{B. Price}

So far there has been no determination of prices or costs incurred to visit the location of the ancient relic sites and Antiquities Collection Room in Jember Regency. Pricing can be in the form of visit packages or entrance tickets to ancient sites and museums.

\section{Place}

During this time all ancient relics were placed in the Antiquities Collection Room of Jember Regency on Dr. Soebandi street, Patrang sub disctric. In terms of location, this place is quite strategic because it is passed by the city transportation lane and is in the middle of the city. It's just that the facilities in it are unfeasible. The condition is still not representative.

Meanwhile, a number of ancient sites in their original locations are scattered in various parts of Jember Regency. Most are located in remote areas, so it takes time and special transportation to reach them. Therefore the existence of the museum becomes very important to determine the feasibility of the location of historical relics in Jember Regency. Determination of the location of the museum also plays a major role in the level of domestic and foreign tourist arrivals. The location of the museum must be in a strategic place, easily accessible to the public and tourists who want to visit, and not far from the city center. Other criteria that need to be taken into account in determining the location of the museum are the availability of parking lots and access for the disabled.

\section{Promotion}

At this time, the Jember Regency Government has not implemented a special promotion strategy to market the historical tourism of Jember Regency. Because the historical tourism branding of Jember Regency has not yet been optimally conceived. Promotions are used through social media and mass media with regional scope, and have not been able to penetrate the national scope. This causes the knowledge of domestic and foreign tourists about the potential of historical tourism in Jember Regency is still not optimal.

Besides through social media, the Jember Regency Government also cooperates with travel service providers, by providing tour packages. But because there is no historical tourism brand in Jember Regency, the package is still not optimally utilized. One of the constraints to this promotion is the limitation of the Department of Tourism and Culture in holding promotions. The entire Jember Regency tourism promotion is currently centered on the Jember Regency Public Relations Section. This makes the active promotion of historical tourism in Jember Regency unable to develop.

\section{E. People}

At this time, there are approximately 20 officers appointed as caretakers. All officers are spreaded in ancient sites in Jember Regency, including officers at Antiquities Collection Room. All officers are under the coordination of the Department of Tourism and Culture of Jember Regency, and work together with the East Java Cultural Heritage Conservation Center. Jember Regency Government also cooperates with some historical communities such as Bhattara Saptaprabhu community and Boemi Poeger community. They act as suppliers of information about historical findings and constraints or damage at historical sites in Jember Regency.

To maximize the role of participants in marketing historical tourism and museums, it requires the involvement of various parties. Not only historical tourism management but also from 
various aspects such as local government, academics, private stakeholders, and the people of Jember Regency.

\section{F. Process}

Historical tourism presents tourists with a diversity of historical evidence. The role of human resources is very large in the process of delivering information about the history of Jember Regency. The optimal process of delivering information can make it easier for tourists to receive the explanation about history of Jember Regency.

\section{G. Physical Evidence}

One physical evidence that can be offered from the historical tourism of Jember Regency is the ancient sites at its original places. Tourists can imagine the lives of past communities through visits to the original site. This atmosphere is an important point in the history of tourism marketing in Jember Regency. This physical evidence is able to bring up the interest of the community to visit historical tourism objects in Jember Regency.

Alternative physical evidence that can be offered through the historical museum of Jember Regency is a representative layout in accordance with the categorization of Jember Regency's historical timeline. So that visitors to the museum can understand the periodization of community life in Jember Regency since prehistoric times to the present. Managers and government can work together with various parties such as private companies in the fields of infrastructure, architecture, graphic design and interior in order to change the look of the museum to be more attractive.

The SWOT analysis enables Jember Regency Government to identify the competitive advantage of historical tourism, namely its unique set of features and products which are considered by the target market to be significant and superior. It is done by identifying strengths, weaknesses, opportunities, and threats. All aspects will be explained as follows:

\section{A. Strength}

1. A collection of relics and history in large numbers and not found in other areas.

2. Prehistoric sites and cultural reserves that are still in their original location.

3. Cultural heritage objects often win in national and international contests.

\section{B. Weakness}

1. Historical heritage objects are stored in places that are not appropriate and are simply placed without historical categorization and periodization.

2. Weak enforcement of law.

3. Media tourism promotion history of Jember Regency is still not optimal.

4. Access to ancient site locations is still limited. 5. Lack of participation from local government, academics, private stakeholders, and the community in optimizing tourism history of Jember Regency.

\section{Opportunities}

1. There is a special segment of domestic and foreign tourists who are interested in historical tourism.

2. Jember Regency is a district that has many public and private universities.

3. Tourism history of Jember Regency can function as a learning center as well as information about the history of Jember Regency

\section{Threats}

1. People who do the destruction and theft of historical objects in ancient sites.

2. There is still an overhaul of the original site and buying and selling ancient collections among the community. 
Based on this analysis, four strategy formulations emerge with each alternative available to be applied. A description of the strategy is as follows:

\section{A. SO Strategy}

1. Provide a special and representative location for the construction of a historical museum. Tourists can be directed to the museum as starting point for an introduction to the history of Jember Regency and its surroundings.

2. Require a museum visit schedule for students. The Jember Regency Government can schedule students' visit to museums and ancient sites. In addition, the government can also include Jember Regency's history curriculum as local content in schools.

3. Introducing the historical tourism area of Jember Regency through audio and visuals at other tourism locations that are often visited by domestic and foreign tourists. For example in the shopping center, nature tourism area, and culinary center. Promotional forms that can be utilized include social media about the history of Jember Regency and displaying photographs of historical relics, making videos about Jember Regency's historical heritage collections and the importance of preserving ancient collections in Jember Regency, smartphone applications to facilitate the public to see the location of ancient sites, and other media. Promotion also involves the mass media in the form of print, radio, television and online media.

4. Initiating effective and consistent branding and image of historical tourism destination in Jember Regency. This step can be applied for historical tourism branding, where Jember Regency is the location of historical development that is not owned by other regions.

\section{B. WO Strategy}

1. Move the collection of historical relics in Antiquities Collection Room of Jember Regency to the historical museum for facilitate supervision and maintenance. The removal of this collection is accompanied by periodization and categorization of historical eras, making it easier for visitors to find out the order of historical development in Jember Regency. It also adds information both audio and visual in each category.

2. Collaborate with other communities to empower activities in the museum. The role of academics is very important in providing information and knowledge, providing education, training and guidance to managers and volunteers in improving museum maintenance, as well as conducting research and community service related to museum management and effective and efficient historical collections maintenance.

3. Provide access to special transportation for the historical expedition of Jember Regency for domestic and foreign tourists.

4. Optimization of stakeholders and external parties in the promotion of historical tourism in Jember Regency. The aim is to build marketing partnerships, develop marketing strategy plans, and develop advertisements and promotions in order to increase the number of tourist visits. It also supports the development of museums by promoting museum education tours to various regions, and systematically gathering information about community needs and experiences.

\section{ST Strategy}

1. Involving the community around the area of ancient sites and museums in its maintenance, to foster a sense of involvement. Communities are invited to share their feelings of historical heritage, hoping to be willing to take care of it without having to move the relic from its original location.

2. Providing opportunities for the surrounding community to participate economically (for example, selling food or drinks, souvenirs, holding shows, etc.). This is done if the 
government or community organizes events in museums or historical sites in Jember Regency. Thus, the economy of the community around the location will develop.

\section{WT Strategy}

1. Organize periodic socialization about the rules of protection of cultural heritage to the community. The socialization can be done by inviting academics, local government, and communities who care about the historical site of Jember Regency.

2. Collaborate with the community or activists in developing the value of local wisdom and supervision of ancient collections and sites. The historical community can be invited to participate in supervising and securing historic objects.

The description of the marketing strategy from the SWOT matrix in the previous section becomes the basis for providing input on the historical tourism marketing strategy model for Jember Regency. This strategy model can be used to develop the historical tourism potential of Jember Regency so that it can increase the Regional Original Income from the tourism sector. In addition, this model can also be used to introduce historical tourism in Jember

This strategy model is further explained as follows:

1. Establish the branding of Jember as a historical tourism area with the slogan Inspiring Heritage. The image of the tourism destination raised is the potential for a long history of Jember from prehistoric times to the present, and how these relics can be an inspiration for the people of Jember and tourists who come to historical tourism objects regarding the glory of Jember in the past to the present.

2. Prepare a historical tour package for Jember Regency through a Jember historical expedition complete with transportation facilities and a competent tour guide. The government and travel service providers can work together with the historical communities of Jember Regency as well as carers and people living around historical heritage sites to provide complete information to tourists who come to these locations.

3. Hold training on tourism procedures to increase the competence of human resources involved in the historical tourism process of Jember Regency. Starting from assisting tourists to delivering coherent and accurate information. This can make it easier for tourists and visitors to understand the historical information provided.

4. The construction of the Jember Museum which displays the historical timeline of Jember Regency is absolutely necessary. Not only to introduce and market all aspects of Jember Regency tourism, but also to save and care for the historical relics of Jember that are scattered in various regions, as well as to socialize the protection of cultural heritage listed in Law Number 11 of 2010 and Regional Regulation of Jember Regency Number

5. Years 2016. Historical objects in the Archaeological Collection Room can be moved to the Jember Museum, plus replicas of historical objects in situ or in their original locations. Tourists who want to get to know Jember can start with a visit to the museum.

6. Gradually, the construction of the Jember Museum is also equipped with facilities for an integrated area of history and cultural arts, such as a hall that can be used to hold various activities. Besides that, it is also equipped with a library and digital learning area that can be used by students and university students to learn the history of Jember Regency. 6 . Cooperate with the Jember Regency Education Office to schedule regular visits of students in the Jember Regency area to the Jember Museum. The government can also include the history of Jember Regency as one of the local content in the student education curriculum.

7. Involve the surrounding community to participate economically in the Jember Museum area and the historical sites of Jember Regency. One of them is by providing a souvenir center area in the museum area. People can sell various products ranging from food and 
beverages, souvenirs, souvenirs, and various handicrafts typical of Jember Regency to be offered to tourists who come to the Jember Museum. In addition, the community around the location of historical sites in Jember Regency can also be empowered as tour guides and provide descriptions of the site's history to tourists and visitors.

8. Creating a calendar of historical tourism activities in Jember Regency which can be done in the Jember Museum area or in Jember Regency historical sites. This activity can be done by involving community participation. One example is the following:

a. January: Tracing the history of Jember Regency in commemoration of Jember Anniversary.

b. February: Journalism competition (photo, video reportage, news, or essay) with the theme of the history of Jember, in the framework of National Press Day.

c. March: Infographic design competition on the history of Jember. The results of this competition can become a reference in the marketing of historical tourism in Jember Regency.

d. April: Cultural arts performance held in the Jember Museum area in the context of Dance Day and Kartini Day.

e. May: History Olympics for students and university students in the framework of National Education Day.

f. June: Archaeological site expedition and deepening of BC civilization. g. July: Jember original product exhibition held in the Jember Museum area.

g. August: Colonial history expedition and Jember independence in commemoration of Indonesian Independence Day. i. September: Photography competition with the theme of the rich historical and cultural heritage of Jember Regency.

h. October: Performing arts theater in commemoration of the Youth Pledge. k. November: Cultural festival for children to commemorate National Children's Day.

i. December: Poster and mural competition for students and the public.

The series of activities and events above can be tailored to the needs and readiness of the Jember Regency Government and its supporting parties.

9. Collaborating with the Jember Tourism Destination Community to develop and promote historical tourism in Jember Regency. Promotion also involves mass media in the form of print media, radio, television, and online. Optimization of stakeholders and external parties must also be done to build marketing partnerships, develop marketing strategy plans, and develop advertisements and promotions in order to increase the number of tourist visits. Private agencies can collaborate in the form of product / service promotion at museum events.

The entire functional strategy described above is the embodiment of the corporate program, namely the Jember Regency Government, which is focused on two things, namely the protection of ancient sites and objects and the development of historical tourism in Jember Regency. This program can be a means to increase Jember Regency regional income from the tourism sector.

\section{Conclusion and Recommendation}

The collection of ancient artifacts from Jember Regency varies greatly with the number reaching more than 600 pieces. The entire collection comes from various eras, from prehistoric eras to colonial eras. Some of the relics are still in their original location or in situ, to maintain its authenticity. However, a number of collections have been moved to the collection of ancient objects storage, with very limited care and storage and the room conditions that are not yet representative. For this reason, the museum is an alternative 
solution as a place for storing a collection of ancient objects, as well as part of historical tourism in Jember Regency.

The presence of the museum in Jember Regency is very much needed as a location for storing ancient objects in Jember Regency. The presence of the museum can also be a source of information for both domestic and foreign tourists to find out a series of history of Jember Regency since prehistoric times to the present. However, the realization of museum development needs to pay attention to various aspects ranging from location, facilities, facilities and infrastructure, availability of supporting information, periodization and categorization of historical relics, and the presence of public spaces that can be used by the public. With the museum, domestic and foreign tourists can understand the history of Jember Regency better. As well as being part of the historical tourism branding of Jember Regency.

Historical tourism strategies have different characteristics from tourism strategies in general. To attract tourists, special strategies need to be implemented.

Academics, both students and lecturers, can provide theoretical input and applications to develop historical tourism in Jember Regency. This input is very important as a reference and knowledge of historical tourism marketing. Students and lecturers can be deployed to conduct research and community service with the aim of developing facilities, infrastructure, facilities and strategies for developing ancient sites. In addition, students can also be agents of change in the community, so that they can invite people to take care and welcome tourists who come to historical relics.

The Jember Regency Government needs to re-construct the construction of Jember Regency Historical Museum. Promotion is the most effective step to attract tourists to Jember Regency. The government, assisted by various parties, can expand promotional activities and submit the implementation of promotional strategies through related parties, both the department and private stakeholders. Synergize with private parties to support and promote historical tourism to various regions. This synergy can also be in the form of information to find out what people want related to the development of historical tourism.

The government must also provide and oversee the application of regulations protecting ancient art collections, to reduce the possibility of damaging and buying and selling historic objects in Jember Regency. It can be done by involve active participation from the community in protecting and developing the historical tourism of Jember Regency.

The description of the marketing strategy from the SWOT matrix in the previous section becomes the basis for providing input on the historical tourism marketing strategy model for Jember Regency. This strategy model can be used to develop the historical tourism potential of Jember Regency so that it can increase the Regional Original Income from the tourism sector. In addition, this model can also be used to introduce historical tourism in Jember.

The entire functional strategy described above is the embodiment of the corporate program, namely the Jember Regency Government, which is focused on two things, namely the protection of ancient sites and objects and the development of historical tourism in Jember Regency. This program can be a means to increase Jember Regency regional income from the tourism sector.

\section{References}

[1] Absalyamova, Albina et al. (2015). Private Museum as a Form of Preservation of Cultural Heritage. Procedia - Social and Behavioral Sciences 188 p218-221.

[2] Ahmad, Zainollah, S.Pd. (2015). Topographia Sacra: Menelusuri Jejak Sejarah Jember Kuno. Yogyakarta: Araska.

[3] Deffner, Alex et al. (2009). Museums, Marketing And Tourism Development: The Case Of The Tobacco Museum Of Kavala. Tourismos: An International Multidisciplinary Journal Of Tourism Volume 4 Number 4 p57-76. 
[4] Gadzala, David. (2014). The Preservation and Stewardship of Archaeological Sites in the Boreal Forest: A Public Issues Approach. Theses: University of Waterloo, Ontario, Kanada.

[5] Hasan, Mahamudul and Jobaid, MD. Imrul. (2014). Heritage Tourism Marketing: Status, Prospects and Barriers. IOSR Journal of Business and Management Volume 16 Issue 5 Ver. IV p40-48.

[6] Ismagilova, Gulnara et al.. (2015). Using Historical Heritage as a Factor in Tourist Development. Procedia-Social and Behavioral Sciences 188 p157-162.

[7] Kotler, Philip and Keller, Kevin Lane. (2009). Marketing Management 13th edition. New Jersey: Pearson Education Inc.

[8] Kotler, Philip et al. (2017). Marketing for Hospitality and Tourism 7th Edition. New Jersey: Pearson Education Limited.

[9] Lamb, Charles W et al. (2011). Marketing 11th edition. Ohio: South Western Cengage Learning.

[10] Martín-Cáceres, Myriam José and Cuenca-López, José María. (2016). Communicating heritage in museums: outlook, strategies and challenges through a SWOT analysis. Museum Management and Curatorship 2016.

[11] Muala, Ayed Al and Qurneh, Majed Al. (2012). Assessing the Relationship between Marketing Mix and Loyalty through Tourists Satisfaction in Jordan Curative Tourism. American Academic \& Scholarly Research Journal Vol. 4, No. 2.

[12] Panosa, Maria Isabel, PhD. (2012). Historical and Arcaheological Heritage and its Social Transfer: Contributions and Challenges. International Journal of Humanities and Social Science Vol. 2 No. 22 p1460151.

[13] Peter, J. Paul and Olson, Jerry C. (2013). Consumer Behavior \& Marketing Strategy 9th Edition Book 1 (translation). South Jakarta: Salemba Empat.

[14] Proulx, Blythe Bowman. (2013). The Preservation and Stewardship of Archaeological Sites in the Boreal Forest: A Public Issues Approach. American Journal of Archaeology 117 p111-125. [15] Suryadana, M. Liga and Octavia, Vanny. (2015). Introduction to Tourism Marketing. Bandung: Alfabeta.

[15] Utama, I Gusti Bagus Rai. (2017). Tourism Marketing. Yogyakarta: Andi Offset.

[16] Widodo, Dukut Imam. (2014). Djember Tempo Doeloe. Jember: PT Jepe Press Media Utama.

[17] Xiao, Wen et al.. (2018). Geoinformatics for the conservation and promotion of cultural heritage in support of the UN Sustainable Development Goals. ISPRS Journal of Photogrammetry and Remote Sensing 142 p389-406. 